\title{
Realidades normativas de la persona jurídica como tercero civilmente responsable en los procesos penales cubanos
}

\author{
Normative realities of the juridical person as civil \\ responsible third in the Cuban criminal process
}

Realidades normativas da pessoa jurídica como terceiro civilmente responsável no processo penal cubano

Leaned Matos Hidalgo ${ }^{1}$

Universidad de Granma - Cuba

lmatosh@udg.co.cu

http://orcid.org/0000-0002-4182-1732

\begin{abstract}
RESUMEN: Este artículo realiza un estudio propositivo acerca de las posibilidades de intervención de la persona jurídica como tercero civilmente responsable en el proceso penal, debido a que en el proceso de actualización del modelo económico cubano, este sujeto es fundamental en la gestión y desarrollo económico del país, pues existen varias brechas de impunidad civil de la persona jurídica, por delitos cometidos por sus agentes, funcionarios, directivos y trabajadores en el ejercicio de sus funciones. En este sentido se hacen coincidir incorrectamente las responsabilidades civil y penal con la persona natural responsable penalmente, aspectos que se discuten en la investigación que se presenta, pues resulta de vital importancia la contextualización de los cuerpos legales que permitan que la víctima obtenga una indemnización directa,
\end{abstract}

1 Licenciada en Derecho. Diploma en Formación de Fiscales. Diploma en Derecho Penal. Profesora Asistente Derecho Procesal Penal de la Facultad de Ciencias Económicas y Sociales de la Universidad de Granma, República de Cuba. Trabajo investigativo resultado del Proyecto "Consultoría Jurídica Rural”, realizado en el 2016 en municipios de la provincia Granma por la Disciplina Derecho de la Empresa. Departamento de Derecho. 
segura y rápida por efectos del juzgamiento penal. Se utilizan los métodos análisis y síntesis, histórico-lógico, exegético jurídico, teórico jurídico y análisis jurídico comparado.

Palabras Claves: persona jurídica; tercero civilmente responsable; proceso penal; disposiciones normativas; contexto cubano.

ABstract: This article carries out a study about the possibilities of the juridical person's intervention as civil responsible third in the criminal process, because in the process of upgrade of the economic Cuban pattern, this fellow is fundamental in the management and economic development of the country, because several breaches of the artificial person's civil impunity exist, for crimes made by their agents, officials, directive and workers in the exercise of their functions. In this sense they are made coincide the responsibilities civilian incorrectly and penal with the natural responsible person penal, aspects that are discussed in the investigation that shows up, because it is of vital importance the upgrade of the norms that allow the victim to obtain a direct, sure and quick compensation for effects of the penal justice. The methods analysis and synthesis are used, historical-logical, juridical, theoretical juridical exegetic and juridical compared analysis.

KEY WoRDs: juridical person; civil responsible third; penal process; normative dispositions; Cuban context.

ResUmo: Este artigo realiza um estudo propositivo sobre as possibilidades de intervenção da pessoa jurídica como terceiro civilmente responsável no processo penal, pois no processo de atualização do modelo econômico cubano, esse sujeito é fundamental na gestão e no desenvolvimento econômico do país, já que existem várias brechas de impunidade civil da pessoa jurídica por delitos cometidos por seus agentes, funcionários, diretores e trabalhadores no exercício de suas funções. Assim, acabam por se coincidir incorretamente as responsabilidades civil e penal com a pessoa natural responsável penalmente, aspectos que se discutem na pesquisa aqui apresentada, pois é de fundamental importância a contextualização dos diplomas legais que autorizam a vítima obter uma indenização direta, segura e rápida em razão do julgamento penal. Utilizam-se os métodos de análise e síntese, histórico-lógico, exegético jurídico, teórico jurídico e análise jurídica comparada.

Palavras-chave: pessoa jurídica; terceiro civilmente responsável; processo penal; disposições normativas; modelo cubano. 
SUMARIO: Exordio. 1. El tercero civilmente responsable en el proceso penal: la persona jurídica. 1.1. Surgimiento, evolución y definición. 1.2. Facultades reconocidas. 1.3 Responsabilidad extracontractual exigida a los terceros civilmente responsables. 1.4. La persona jurídica como tercero civilmente responsable. 2. La persona jurídica como tercero civilmente responsable en los procesos penales cubanos. 2.1. Antecedentes 2.2. Particularidades normativas de la persona jurídica como tercero civilmente responsable en el proceso penal cubano. 2.3. Propuestas para el perfeccionamiento. Conclusiones. Bibliografía.

\section{EXORDIO}

En un proceso penal, además de la exigencia de la responsabilidad de este tipo, que es evidente por la naturaleza del hecho que se comete, también, en algunos supuestos, se deriva la responsabilidad civil producto del delito o por las consecuencias ocasionadas por el hecho delictivo, la que obliga al que lo causa a resarcir a la víctima o perjudicado por el daño o perjuicio ocasionado.

Lo más importante, en este sentido, y que se trae a colación en esta búsqueda, es que la responsabilidad civil no sólo alcanza a los criminalmente responsables, sino también a terceras personas que en distintos conceptos pueden venir sometidas a ellas, dentro de los que se encuentra, la persona jurídica en el caso de ser un funcionario o empleado en el cumplimiento de sus funciones.

Visto de esta forma, la responsabilidad civil de la persona jurídica en el proceso penal, no nace directamente de un acto delictivo, del que queda sujeto a ella, debido a que sin tener intervención en la ejecución del delito, ni en ninguna de las formas que integran la responsabilidad criminal, pueden incurrir en la civil, unas veces como principal obligado y otras, subsidiariamente en defecto de los responsables criminalmente, todos los que resultan implicados en el mismo proceso donde se exige una sanción por la comisión de un hecho delictivo.

Por lo que resulta complejo, para el tribunal, como sujeto procesal director, ubicado jerárquicamente en un eslabón superior, en la relación 
jurídica procesal penal, el juzgamiento de un sujeto procesal, que la razón de su intervención es distinta a la del imputado, y de la propia especialización del tribunal; motivos que igualmente limitan el ejercicio de la acción conjunta del sujeto activo o acusador y la postulación procesal de la persona jurídica como tercero que responde civilmente.

Por otra parte, y, de hecho, una de las motivaciones fundamentales de la actuación de los terceros civilmente responsables en el proceso penal, y, por ende, de la persona jurídica en este concepto, es evitar la victimización secundaria, poniendo al inmolado en el centro del proceso, asegurando el perfeccionamiento del Debido Proceso, respecto a los derechos y garantías de los sujetos procesales (principales y secundarios) en igualdad de condiciones, aspectos que resultan en reformas procesales.

En el caso de Cuba, se estipula en las normas jurídicas procesales la intervención de la persona jurídica como tercero civilmente responsable, pero resulta insuficiente y a la vez contradictoria para muchos profesionales del Derecho la forma en la que vienen reconocidas y tratadas en el proceso penal; debido a que se identifican como acusados civilmente responsables, obviando la naturaleza civil de este sujeto, no se definen los actos procesales que puede realizar dentro del proceso ni los derechos y facultades que le asisten a la persona jurídica como tercero civilmente responsable; criterios que obstaculizan los objetivos anteriormente señalados.

Es por ello, que dentro del proceso de fortalecimiento de la institucionalización en el país, que conlleva a la actualización del modelo económico y al perfeccionamiento del ordenamiento jurídico, la intervención de la persona jurídica como tercero civilmente responsable en el proceso penal, se hace tema obligado; pues es pertinente la inclusión de modificaciones legislativas, que permitan utilizar coherentemente el principio de economía procesal y satisfacer los intereses materiales de la víctima como perjudicada por el hecho delictivo, aspectos que resultaran de este trabajo.

Por lo cual se designa como Problema Científico de la investigación: La inadecuada regulación de la intervención de la persona jurídica como tercero civilmente responsable en el proceso penal cubano, acarrea un sistema procesal ineficaz, y, por ende, una insatisfacción de los intereses materiales de la víctima del delito. Para el desarrollo del tema, se plantea 
como Objetivo General: Fundamentar el perfeccionamiento del sistema procesal penal cubano en cuanto a la regulación de la persona jurídica como tercero civilmente responsable, a partir de la teorización de los elementos fundamentales, el estudio de normas penales adjetivas foráneas y el análisis de la normativa cubana acerca de esta institución, a fin de la satisfacción material de las víctimas del delito y el respeto al debido proceso.

\section{El tercero CiVilmente ReSPONSAble EN EL PROCESO PENAL: LA PERSONA JURÍDICA.}

\subsection{SURGIMIENTO, EVOLUCIÓN Y DEFINICIÓN}

La organización judicial en sus inicios, con el Derecho Romano fundamentalmente, concebía a través de las fórmulas del sistema de enjuiciar una continuidad de actos que eran responsabilidad exclusivamente del órgano creado al efecto, a pesar de que ponía en conocimiento el hecho cualquier persona de la ciudadela.

En consecuencia, con el sistema acusatorio puro, la víctima ejercitaba la acción penal, pero el resto de los actos del proceso eran guiados por aquellos magistrados designados por el Imperioº $^{2}$, viéndose la inexistencia del tercero civilmente responsable en cualquiera de sus variantes, debido a que no evidencia en ninguna literatura consultada.

Posteriormente, con el sistema inquisitivo aparece la división en fases, aunque todavía el poder judicial se encontraba en manos de los que ejercían el poder político, por lo que todas las acciones y actos que se realizaban en el proceso, que tenía como finalidad sancionar a una persona responsable de un hecho prohibido, peligroso socialmente y además en contra de los cánones espirituales y morales, eran los mismos sujetos, aquellos que pertenecían a la Iglesia Católica y se nombraban juzgadores de conductas prohibidas y contra los cánones establecidos por la propia Iglesia.

2 Véase: FERNÁNDEZ PEREIRA, Julio A. El Derecho Procesal Penal. Concepto y naturaleza del proceso penal. Evolucion historica. Los sistemas de enjuiciar. En: AA.CC. Temas para el estudio del Derecho Procesal Penal. Tomo I. La Habana: Félix Varela, 2002. p. 4-10. 
Recuérdese que, en esa etapa primaria, el propio sujeto que recibía la denuncia o anónimo era el encargado de investigar, detener, interrogar al sospechoso para arrancarle su confesión, dictar su sentencia, y hasta ejecutarla. La estructura organizativa durante el predominio del sistema inquisitivo, si bien generó alguna especialización de funciones y hasta de sujetos, como lo muestra el lejano antecedente del Ministerio Público, surgido en Flandes, en 1163, de lo que después sería la Fiscalía, sin embargo, mantuvo la centralización de esta actividad ${ }^{3}$, y con ello, la quimera de los terceros civilmente responsables, tanto personas naturales como jurídicas.

Con el triunfo de la Revolución Francesa, en 1789, las ideas de la tripartición de poderes y la función de cada órgano estatal, se desmontó el sistema inquisitivo que se conocía hasta el momento y se instituyó el sistema acusatorio moderno o mixto que conocemos hoy.

Empero, la actividad judicial fue desarrollando nuevas figuras procesales y al mismo tiempo hizo una determinación de sus funciones, con la instrucción del proceso, la investigación, la policía judicial, los peritos, la parte que formulaba la acusación, los jueces encargados de dictar sentencia y los encargados de la ejecución de estas, los defensores de oficio ${ }^{4}$ y otros que intervenían en el proceso que no tenían ningún tipo de denominación, o sea eran simples contribuyentes en la realización del proceso penal.

La intención de participar en un proceso penal por parte de cualquier persona, llega a legitimarse con las propias formas de juzgar que establece el poder judicial, encargando a varios sujetos actuaciones en un determinado proceso, es por ello que suelen coincidir en algunos países los sujetos procesales en sede penal, pero en otros las responsabilidades cambian y por tanto el sujeto procesal ${ }^{5}$. De aquí en adelante se estipulan diversas teorías acerca de los sujetos procesales, convirtiéndose en aquellos que intervienen en algún momento procesal de la persecución penal, es aquí, por primera vez, que se comienza a tratar el tema de los terceros civilmente responsables en los procesos penales.

\footnotetext{
3 Véase: BODES TORRES, Jorge Leslie. Reflexiones sobre las etapas procesales y los sujetos responsables. Sociedad Mexicana de Criminología. Capítulo Nuevo León, A.C. México. 2008

4 Ídem.

5 Ibídem.
} 
Según Claria ${ }^{6}$, el tercero civilmente responsable es el sujeto particular y accesorio, que por citación o espontáneamente, se introduce en el proceso cuando se ejerce en él la acción civil, por afirmarse que conforme al derecho privado ha de responder por el daño causado con el delito que se atribuye al imputado.

Mendoza $^{7}$, por su parte, conceptualiza a los terceros civilmente responsables como aquellos sobre quien recae la acción resarcitoria en un proceso penal y que tienen la obligación de responder subsidiariamente por el acusado.

En ambos conceptos, no se define la naturaleza del sujeto de derecho o de la persona que puede resultar tercero civilmente responsable en el proceso penal, lo que se debe entender, a partir del análisis de la legislación civil y penal, sustantiva y adjetiva, que fijan en concreto cuando las personas naturales y jurídicas son obligados como terceros con responsabilidad civil en el proceso penal.

Por tanto, se entiende para la presente, que los terceros civilmente responsables o terceros con responsabilidad civil en el proceso penal, son aquellos sujetos (personas naturales y/o jurídicas) que intervienen en un proceso penal, para responder en cuanto a la responsabilidad civil que se deriva del daño o perjuicio ocasionado por el delito, de forma directa o indirecta.

En este sentido, existen dos grandes grupos dogmáticos, los que asumen una posición restrictiva o estricta y los que asumen una posición extensiva o amplia, acerca de la concepción de este sujeto como procesal para el proceso penal. Véanse algunos ejemplos sobre estepreliminar:

\section{POSICIÓN ESTRICTA}

Fairén ${ }^{8}$ hace referencia dentro de los elementos del proceso penal a "los sujetos como el elemento fundamental y protagónico del

6 CLARÍA OLMEDO, Jorge A. Derecho procesal penal. Tomo I. Actualizado por Vázquez Rossi, Jorge E. Editores Rubinzal-Culzoni. Buenos Aires. Argentina. 1998. p. 265.

7 MENDOZA DÍAZ, Juan. Derecho procesal. Parte general. Edición Electrónica. La Habana. Cuba. 2014 p. 338 y 339.

8 FAIRÉN GUILLÉN, Víctor. Teoría General del Derecho Procesal. Instituto de Investigaciones Jurídicas. Serie G. Estudios Doctrinales. No. 133. Universidad 
proceso, pues estos son los encargados de ejecutar en plazos determinados de tiempo, los actos y acciones que desarrollan y fundamentan, la investigación, las pretensiones de las partes y la decisión respecto al hecho presuntamente delictivo".

Según Álvarez "el proceso penal se desarrolla por la sucesión de actos procesales de los sujetos procesales, dígase las partes y el tribunal, amén de que otras personas intervengan en el proceso penal. Los actos procesales que conforman el proceso y recaen sobre el objeto del mismo son la acusación, la defensa y la jurisdicción”.

Roxin ${ }^{10}$, por su parte, define los sujetos del proceso penal como "aquellos, del procedimiento, quienes representan la cara visible del proceso penal, son el imputado y su defensor, la fiscalía, el tribunal y el ofendido. Se habla de esas personas como de los sujetos del proceso porque ellas disponen siempre de derechos autónomos en el procedimiento".

Por otra parte, Moras ${ }^{11}$ explica que "en la actividad constante que implica el proceso, en el que paso a paso, de situación en situación, progresivamente se avanza irretornablemente hacia una meta final que es la sentencia, intervienen personas que, reguladaspor la ley formal, tienen a su cargo el cumplimiento de diferentes roles. Así, en torno a éstos, aquéllas se agrupan alrededor de la función de promover, impulsar y demandar penas, todo lo cual constituye la acusación. Frente a ella se nuclea el acusado y las personas que lo asisten. Todo llevado ante el órgano jurisdiccional que es el que decide”.

En relación al tema, Oliva $^{12}$, afirma que "pueden considerarse sujetos procesales aquellos que inciden directamente en la relación jurídica procesal penal, resaltando a los órganos jurisdiccionales”.

Nacional Autónoma de México. México. 1992. p. 20.

9 ÁLVAREZ TORRES Y COLS, Osvaldo. Generalidades del Derecho Procesal. En: Compilación de Temas de Derecho Procesal para Estudiantes de Derecho. Editorial Universitaria. La Habana. Cuba. 2012. p. 6.

10 ROXIN, Claus. Derecho procesal penal. Editorial Editores del Puerto s.r.l. Buenos Aires. Argentina. 2000.p. 121.

11 MORAS MOM, Jorge R. Manual de Derecho Procesal Penal. Editorial LexisNexis Abeledo - Perrot. Buenos Aires. Argentina. 2004. p. 42-43.

12 OLIVA SANTOS, Andrés. Los sujetos del proceso penal. En: Derecho Procesal Penal. Sexta Edición, Centro de Estudios Ramón Areces, Madrid, 2003. 
Los autores que se afilian a la teoría restrictiva de los sujetos procesales, argumentan en sentido general, que los sujetos procesales dentro del proceso penal son aquellos que intervienen directamente en la relación jurídica procesal penal, el resto de los sujetos que intervienen de una forma u otra en el proceso, son simples contribuyentes al desarrollo de la justicia.

\section{Posición extensiva}

Ahora bien, en cuanto a la idea de concebir solamente a los sujetos procesales según la posición restrictiva, no se podría calificar a los terceros civilmente responsables dentro de los sujetos procesales penales, pues ciertamente estos son parte de una relación jurídica procesal, pero no penal, sino de una relación jurídica procesal civil especial, donde dicha relación jurídica procesal civil es derivada y se desarrolla paralelamente a la relación jurídica procesal penal, donde las partes son la Fiscalía y/o el coadyuvante en representación de la víctima y los intereses estatales (demandante) y el tercero civilmente responsable (demandado).

Otra idea que se maneja en la doctrina ${ }^{13}$, es la de considerar a los terceros civilmente responsables como sujetos procesales para el proceso civil que se desarrolla colateralmente al proceso penal, cuando existe un supuesto de responsabilidad civil de las estipuladas en la legislación civil y penal, pero no sujetos procesales dentro del proceso penal, lo que a nuestro entender sería desacertado, pues estamos hablando de un único proceso y de naturaleza penal, por lo que deben concebirse sujetos procesales para este único proceso los terceros civiles demandados.

Respecto a la concepción amplia o extensiva de los sujetos procesales y la consideración de los terceros civiles demandados como sujetos procesales, se pueden mencionar otros tratadistas, entre ellos, Vázquez $^{14}$; “quien asevera que los sujetos procesales son aquellas per-

13 GALVEZ PUEBLA, Inés. La ejecución de la responsabilidad civil derivada del delito en Cuba. Tesis doctoral. Universidad de La Habana. Cuba. 2009; MARIN, J.C. La acción civil en el nuevo Código Procesal chileno: su tratamiento procesal. Revista de Estudios de Justicia. Chile. 2005.

14 VÁZQUEZ ROSSI, Jorge E. Derecho Procesal Penal. Tomo II. El Proceso Penal. Editorial Rubinzal-Culzoni. Buenos Aires. Argentina. 1997. p. 61. 
sonas de existencia físicaque intervienen dentro del proceso y de las cuales emanan actos con relevancia para la investigación, discusión y decisión de la cuestión sometida u objeto procesal, por lo que actúan en el proceso penal conforme a las atribuciones y sujeciones que les asigna la ley para hacer valer, oponer o satisfacer directamente las pretensiones fundamentadas en el objeto procesal. En todo caso debe tratarse de la pretensión penal, y eventualmente en lo civil; pero no puede dejar de ser inmediata la vinculación con el hecho imputado y con la actuación del derecho en lo que a ese hecho respecta”.

Igualmente refiere Vázquez, que la existencia de dos clases de sujetos procesales, los necesarios y los eventuales, siendo los primeros aquellos sin los cuales no puede existir la relación jurídica procesal integrada por la acusación, defensa y decisión, como se advierte tales sujetos aparecen como órganos que concretan los respectivos poderes de acción, defensa y jurisdicción, indispensables para la constitución del proceso penal, derivados además de normas fundamentales que constituyen presupuestos para su actuación ${ }^{15}$.

Por su parte, Carnelutti ${ }^{16}$ refiere a los sujetos del proceso, aquellos que "interceden directamente en el proceso, que están sujetos a la naturaleza del hombre. La antropología, sociología criminal, la psicología criminal, la naturaleza del delito y su remedio procesal, son aspectos que definen a las personas que intervienen en la realización del proceso".

Igualmente sobre el tema, Levenne ${ }^{17}$ sitúa como "personas que actúan en un proceso, a los sujetos procesales, partes y terceros. Los sujetos procesales pueden ser principales y secundarios. Para que la relación procesal se constituya son indispensables los primeros, a saber, el juez, acusador (ministerio público o querellante), y el acusado, a quienes corresponde, respectivamente, las tres funciones de decisión, acusación y defensa”.

15 Ídem.

16 CARNELUTTI, Francesco. Cuestiones sobre el proceso penal. Traducción de Santiago Sentís Melendo. Editorial Librería del Foro S. A. Buenos Aires. Argentina. 1994. p. 187-225.

17 LEVEnNE, Ricardo. Manual de Derecho Procesal Penal. 2da edición. Tomo I. Editorial Depalma. Buenos Aires. Argentina. 1993. p. 227-228. 
En relación a la delimitación de sujetos principales y secundarios, distingue ${ }^{18}$ a los sujetos secundarios son la parte o actor civil, el civilmente demandado o responsable por el daño resultante del delito, y el civilmente obligado al pago de la multa. Sin los sujetos principales no puede existir la relación procesal; por la ley tienen el poder jurídico de accionar, de resistir o de defenderse y de decidir, o sea, tienen potestad de acusación, de defensa y de jurisdicción; los secundarios pueden intervenir en la relación procesal penal por un interés civil que hacen valer en ella con autorización de la ley.El sujeto pasivo del delito no es sujeto de la relación procesal, ni tampoco parte, salvo que esté facultado a constituirse en parte civil, en cuyo caso será un sujeto secundario.

$\mathrm{Gil}^{19}$ aprecia que los sujetos principales en el desarrollo de los procesos penales, ante jurisdicción nacional e internacional, "son aquellos que tienen la obligación de investigar y comprobar el hecho, los que persiguen el castigo para los comisores de los delitos, los que plantean hipótesis contradictorias sobre la ejecución del hecho en defensa del responsable, el responsable y los que deciden sobre las consecuencias de la comisión del delito". Coincidiendo con la identificación del tercero civilmente responsable como sujeto procesal.

Además, explica Bauman ${ }^{20}$ "que en el proceso penal obran muchos sujetos procesales en posiciones muy diferentes y con muy diferentes cometidos. Pueden formarse tres grupos principales: el tribunal y los auxiliares del tribunal como entidad de decisión; los sujetos procesales en la función activa o acusatoria: ministerio público y auxiliares, acusador privado y acusador conjuntos; por último, los sujetos procesales en la función pasiva o parte acusada: imputado y defensor”. No obstante, ofrece una categoría muy particular de sujetos procesales "otros sujetos procesales”, refiriéndose a la asistencia judicial prestada a menores, los testigos, los peritos, autoridades administrativas y los terceros intervinientes.

18 Ídem

19 GIL GIL, Alicia. Bases para la persecución penal de crímenes internacionales en España. Editorial Comares. Granada. España. 2006. p. 47-66.

20 BAUMANN, Jurgen. Derecho procesal penal. Conceptos fundamentales y principios procesales. Introducción sobre la base de casos. Editorial Depalma. Buenos Aires. Argentina. 1986. p. 130 y 212-216. 
Una vez relacionadas las más disímiles posiciones, se considera que los sujetos procesales son todas aquellas personas públicas o privadas, naturales y jurídicas, que intervienen necesaria o eventualmente en el proceso penal, para hacer valer sus pretensiones, a través de una sucesión de actos procesales. Estos sujetos van a ser titulares de los poderes de jurisdicción, acción o defensa, puestos en acto ante la presencia de un concreto objeto procesal penal; acogiéndose el artículo a la posición extensiva.

\subsection{FACULTADES RECONOCIDAS}

Ahora bien, teniendo en cuenta, que los terceros civilmente responsables, son igualmente sujetos procesales, las normas adjetivas reconocen una serie de derechos y garantías, que posibilitan el respeto al debido proceso dentro del proceso penal, de forma que se protege la participación de este, de igual forma que la del imputado/ acusado en el proceso.

FACULTADES PARA LA INSTRUCCIÓN:

- Ser parte civil en el proceso cuando es parte el procesado penalmente.

- Participar en las acciones de instrucción/ investigación para el esclarecimiento del hecho.

- Podrá solicitar durante el sumario todas las providencias útiles para la comprobación del delito y la determinación de los culpables, debiendo estarse a lo que el instructor, fiscal o Juez de instrucción resuelva.

- Podrá declarar como tercero civil responsable o como testigo dentro del proceso.

Facultades para FASE INTERMEDIA Y DE JUICIO ORAL:

El tercero civilmente responsable una vez considerado como tal, goza de las mismas facultades concedidas al imputado para su defensa, en lo concerniente a sus intereses civiles. 
- Solicitar su intervención en el proceso cuando pueda ser civilmente demandado y se ejerza la acción civil resarcitoria.

- Debe de participar con el patrocinio de un abogado.

- Puede acogerse al derecho de no autoincriminación.

- Puede ser parte civil y testigo para alguna de las partes penales.

- Participar mediante su abogado en la práctica de medios de prueba.

- Rendir informe final en juicio mediante abogado, sobre el concepto de la responsabilidad civil.

- Puede recurrir la sentencia que declare su responsabilidad.

\subsection{RESPONSABILIDAD EXTRACONTRACTUAL EXIGIDA A LOS TERCEROS CIVILMENTE RESPONSABLES}

Los terceros civilmente responsables pueden ser personas naturales y personas jurídicas, partiendo del tipo de responsabilidad civil que puede exigirse en el proceso penal, las que son:

\section{RESPONSABILIDAD CIVIL EXTRACONTRACTUAL INDIRECTA}

Ese denominado "indirectamente responsable" por el hecho de otro responde en realidad por una falta suya, propia y distinta de la del vigilado o educando. La responsabilidad civil por el hecho ajeno se erige entonces a consecuencia de haber faltado el llamado por ley a responder, al deber jurídico concreto de vigilar, elegir y educar; lo que en el fondo constituye una garantía que ofrece la ley a los damnificados en aras de esa debilidad a que antes se hacía referencia. Ello ha permitido derivar, además, tres requisitos para que surja la responsabilidad civil extracontractual indirecta del tercero $\left.{ }^{21}: 1\right)$ La existencia de un vínculo de subordinación o dependencia entre el civilmente responsable y el

${ }^{21}$ CÓRDOVA ÁNGULO, Miguel. Anotaciones sobre el tercero civilmente responsable en el procedimiento penal colombiano. Revista Derecho Penal y Criminología, vol. 34, no. 96, enero-junio 2013, Bogotá, Universidad Externado de Colombia, 2013, p. 57-81. 
directamente responsable. 2) La verificación del deber de cuidado y control que le asiste al civilmente responsable, respecto del directamente responsable y 3) La culpa del directamente responsable en la irrogación del perjuicio.

\section{RESPONSABILIDAD CIVIL EXTRACONTRACTUAL DIRECTA}

En principio, la responsabilidad civil extracontractual directa, en el caso de que la conducta dañina constituya delito, compete a quienes son responsables penalmente en calidad de autores o partícipes de la conducta punible, de manera que parecería imposible que alguien que no hubiera tomado parte en el delito fuera llamado a responder por un hecho propio. Sin embargo, esta afirmación solo es válida de cara a las personas naturales. En efecto, toda persona natural que sea responsable civilmente con carácter directo por un delito debe ser, en consecuencia, vinculada al proceso para responder penalmente, pero cuando los responsables son personas naturales dependientes de una persona jurídica, ya sea al nivel directivo o al operativo, y su conducta se da en desarrollo del objeto social de esa persona jurídica, se entiende que el ente en cuestión ha actuado a través de sus dependientes, de modo que sus delitos o culpas le son igualmente imputables.

\subsection{LA PERSONA JURÍDICA COMO TERCERO CIVILMENTE RESPONSABLE}

Se concuerda en determinar que la razón de ser de las personas jurídicas es la existencia de fines que claramente exceden de las posibilidades de las personas naturales o individuales, por ello, fue necesaria la creación de un ente que por medio de la agrupación de voluntades o de patrimonio, logre los fines del desarrollo social.

Existen varias teorías acerca de la naturaleza de la persona jurídica, las que se agrupan en dos grandes grupos: las de ficción y las realistas, aunque existen varias posiciones intermedias. Las teorías de ficción conciben que la capacidad jurídica puede ser extendida a sujetos artificiales creados por simple ficción, tal sujeto es la persona jurídica, capaz de tener patrimonio propio. 
Según Capilla Roncero ${ }^{22}$, a propósito de esta teoría, "es una fictio iuris, que quiere indicar que aquella situación, sin ser de una determinada manera en la realidad, merece esa consideración determinada para el ordenamiento jurídico".

En cuanto a las teorías realistas, rechazan toda ficción y sientan como base que el concepto de persona no coincide con el hombre, sino con el sujeto de derecho, por lo que no se excluye que haya sujetos de derechos que no sean hombres, como es el caso de las personas jurídicas.

Existen igualmente las teorías socialistas, que no se desgastan en explicar si la persona jurídica es una realidad o una ficción, sino que centran su análisis en el Estado como principal sujeto colectivo, aunque no desconocen el resto de las personas jurídicas.

Por lo anteriormente explicado, se esgrimen varios conceptos de lo que se considera persona jurídica, según Ferrara ${ }^{23}$ las personas jurídicas son las asociaciones o instituciones formadas para la consecución de un fin y reconocidas por la ordenación jurídica como sujetos de derecho. Por otra parte para Castán ${ }^{24}$ es la entidad formada para la realización de los fines colectivos y permanentes de los hombres, a la que el derecho objetivo reconoce capacidad para derechos y obligaciones.

Por lo tanto, para la presente, la persona jurídica es la agrupación de personas individuales o patrimonio, reconocida por voluntad estatal en el ordenamiento jurídico como sujeto de derecho y con una estructura orgánica que le permita cumplimentar los fines económicos y sociales para los cuales fue creada.

Para la constitución ${ }^{25}$ de la persona jurídica se deben tener en cuenta varios elementos: el patrimonio propio, la unidad orgánica, actuar jurídicamente en nombre propio y la responsabilidad independiente.

22 CAPILLA RONCERO, Francisco. La persona jurídica: funciones y disfunciones. Editorial Tecnos. Madrid. España. 1993. p. 45

23 FERRARA, Francisco. Teoría de las personas jurídicas. Editorial Reus. Madrid. España. 1929. p. 168.

24 CASTÁN TOBEÑAS, Jose. Derecho civil común y foral. Editorial Reus. Madrid. España. 1943. p. 396.

25 Existen varios sistemas de constitución de las personas jurídicas, el administrativo, que es aquel según el cual la persona jurídica nace por una decisión estatal que determina la constitución del ente (empresas estatales); el de 
Respecto a esta última, implica que la persona jurídica al actuar en el mundo jurídico, adquiere derechos, pero al mismo tiempo obligaciones, las cuales debe cumplir con su patrimonio propio. Es por ello, que la capacidad jurídica que posee la persona jurídica se manifiesta en las sedes: civil (patrimonial, obligacional, extracontractual, contractual, testamentaria), penal, mercantil, laboral, económica, financiera y administrativa.

Resultando del ejercicio de esta capacidad jurídica, los supuestos de responsabilidad por los que viene obligada la persona jurídica. Entre ellas se encuentran la responsabilidad civil, la penal y la comercial.

Respecto a la responsabilidad civil, que es objeto de este trabajo, la persona jurídica responde por los actos realizados por sus agentes, funcionarios o empleados, por lo que siempre sería denominada tercero civilmente responsable en el proceso en cuestión, en este caso se trae a colación en la investigación, la responsabilidad civil de la persona jurídica cuando el acto ilícito que comete el agente, funcionario o empleado es de naturaleza penal, y por tanto, los hechos se ventilan en un proceso penal.

En el caso de las personas jurídicas, cuando se les imputa responsabilidad civil directa, estas pueden ser llamadas a responder como terceros civilmente responsables en un proceso penal, única y exclusivamente, por el hecho de sus agentes y nunca por la conducta de terceros ajenos a la misma; igualmente pueden ser convocadas como terceros civilmente responsables, si se les imputa responsabilidad civil indirecta. ${ }^{26}$

En cuanto a la responsabilidad civil extracontractual directa de las personas jurídicas ${ }^{27}$, tiene las siguientes características sustanciales centrales:

1. La culpa de cualquier agente del ente lo compromete, sin importar que se trate de un miembro directivo o ejecutivo de la persona jurídica. Sin embargo, es indispensable que sea un

autorización, según el cual la persona jurídica requiere la autorización de un órgano del Estado (asociaciones) y el normativo sin permiso previo o sistema de concesión, que reconoce como persona jurídica a aquellos entes que se constituyan conforme con el contenido indicado y las condiciones impuestas por la ley (cooperativas de créditos y servicios, de producción agropecuaria).

26 CÓRDOVA ÁNGULO, M. Ob. cit.

27 Ídem. 
agente o dependiente del ente moral en cuestión que, además, hubiere cometido la culpa en ejercicio de sus funciones.

2. La demostración de la responsabilidad del dependiente es suficiente para acreditar la de la persona jurídica, sin que valga para esta demostrar que fue diligente en la elección o la vigilancia del dependiente. En efecto, no debe perderse de vista que, al ser una manifestación de la responsabilidad directa, se rige por las normas generales y no por los presupuestos de la indirecta o por el hecho ajeno.

3. Por lo anterior, ante la culpa del dependiente, la persona jurídica solo se exonera demostrando que el daño fue causado por un hecho ajeno -caso fortuito, hecho de un tercero o culpa de la víctima. En cuanto al "hecho de un tercero" como causal de exoneración, vale notar acá que las acciones de quienes no son agentes o dependientes de la persona jurídica se entienden como conductas de terceros, pues estos no tienen legitimación para actuar a nombre de la persona jurídica y sus conductas no pueden incorporarse a la voluntad de esta.

4. Existe responsabilidad solidaria entre la persona jurídica y el ejecutor de la conducta dañina, pudiendo aquella repetir contra este.

Esto no quiere decir, como es lógico, que cualquier actuación de un subordinado que genera daños provoca una responsabilidad civil de la persona jurídica o del Estado, sino que deben concurrir ciertas condiciones. La doctrina civilista ha desarrollado reglas de aplicación similares a la imputación objetiva del Derecho Penal, para establecer la estructura de la culpa extracontractual, algo que dice de la aproximación de la responsabilidad civil "ex delito" a la responsabilidad civil por daño. ${ }^{28}$

En efecto, ha de partirse que, en el ámbito de la responsabilidad de las personas jurídicas, ya sea civil, mercantil o administrativa, siempre estamos ante una responsabilidad vicarial (vicarius labillity), esto es, es un sujeto quien actúa y otro, la persona jurídica, quien responde. Lo

28 QUINTERO OLIVARES, Gonzalo. De la responsabilidad civil derivada de los delitos y faltas y de las costas procesales. In: QUINTERO OLIVARES (DIR.). Comentarios al nuevo código penal, Navarra, Aranzadi, 1999, pág. 549. 
determinante es establecer qué conductas, o más propiamente, el comportamiento de qué sujetos compromete en su responsabilidad a la persona jurídica. Este es un tema, que ha servido de fundamento para sostener que no es admisible la responsabilidad penal de las personas jurídicas, porque ésta es de carácter personal, por consiguiente, no hay identidad entre el sujeto que actúa y el que responde. No obstante, ha de recordarse que, incluso en el ámbito penal se reconocen casos de responsabilidad vicarial, como "el actuar en nombre de otro" y la autoría mediata.

Determinar el comportamiento y, más concretamente, el sujeto que compromete en su responsabilidad a la persona jurídica ha sido resuelto en el ámbito civil con la teoría de la representación: la actuación del representante compromete a la persona jurídica. Ésta solución también ha sido acogida en el ámbito penal con la figura del actuar en nombre de otro, ya antes citada. Las diversas fórmulas del Derecho Comparado de ésta institución, aunque con distintos alcances en el derecho positivo, poseen en común el reconocimiento de la actuación de un sujeto que compromete con su comportamiento a la persona jurídica. Dicho ámbito de sujetos, que en sus primeras regulaciones era un sujeto formal (el representante legal), ha ido ampliándose a sujetos materiales, esto es, personas que, aunque no posean un reconocimiento jurídico para representar a la persona jurídica, actúan materialmente comprometiéndola y actuando en su beneficio. Es lo que en doctrina se denomina el representante de hecho. ${ }^{29}$

Trasladando esta argumentación al ámbito de la responsabilidad civil que, como se ha dicho es admisible a fortiori, pues si se admite para la actuación del subordinado, con mayor razón ha de admitirse para el directivo que actúa en representación material, quien tiene capacidad de comprometer a la persona jurídica a hacer o no hacer algo y, actúa en beneficio o interés de la persona jurídica.

La afirmación de la responsabilidad civil, como tercero civilmente responsable, de la persona jurídica por delitos cometidos por sus directivos se fundamenta, además, en un principio de justicia material de Derecho Civil, que proviene del Derecho Romano: quien se beneficia

29 GARCÍA CAVERO, Percy. La responsabilidad penal del administrador de hecho de la empresa: Criterios de imputación. Barcelona, J.M. Bosch, 1999. p. 173. 
de una actividad responde también por los daños que ella cause. Últimamente se sigue más la teoría del riesgo, importada de Alemania, como fundamento de quién debe responder frente a los daños causados. MEINI la ha explicado bien: "quien se organiza para realizar una determinada actividad económica ( $y$, en general cualquier actividad) en cuya virtud despliega cursos causales de riesgo, así como hace suyos los beneficios que se obtienen por la explotación de la referida actividad, debe hacer suyos también los perjuicios"30. Nótese que esta fundamentación es para argumentar la posición de garante de los directivos respecto a los delitos cometidos por sus subordinados, a los efectos de afirmar la responsabilidad penal en comisión por omisión. Nuevamente, con mayor razón, servirá para afirmar la responsabilidad civil de la propia empresa, por los daños y perjuicios causados por los delitos cometido por los directivos.

Una vez establecidos los fundamentos de la responsabilidad civil de la persona jurídica como tercero civilmente responsable, es menester señalar cuáles requisitos deben de tenerse en cuenta para establecer dicha responsabilidad, los cuales se plantean por Zuñiga Rodríguez ${ }^{31}$ de la siguiente forma:

1. La responsabilidad civil de la persona jurídica por el delito cometido por su directivo se fundamenta en la finalidad de reparación de daño causado, es decir en la existencia de un daño causado por el delito, que, no obstante, su carácter civil, ha de reconocerse que esta consecuencia jurídica del delito se inscribe dentro de una condena penal, desplegando una serie de efectos aledaños a la sanción penal.

2. Actuar en beneficio o interés de la persona jurídica. Requisito que sirve para distinguir la criminalidad desde la empresa, cuando esta es un instrumento para la comisión de delitos, de la criminalidad de los managers o delitos societarios en la que los directivos actúan en su propio beneficio.

30 MEINI, Iván. Responsabilidad penal del empresario por los delitos cometidos por sus subordinados. Valencia, Tirant lo Blanch, 2003, p. 313.

31 ZUÑIGA RODRÍGUEZ, Laura. A propósito de la responsabilidad civil de la persona jurídica por delito. Tomado de: <http://www.perso.unifr.ch/derechopenal/assets/files/articulos/a_20080527_54.pdf>. 
3. Proporcionalidad de la consecuencia jurídica. Éste es un principio que rige toda restricción de derechos por parte del Estado. La fijación del monto de la reparación civil no escapa a dicha regla. El juez debe fijar la reparación civil en proporción al daño causado, en primer lugar, y, en segundo lugar, a la capacidad económica de los sujetos imputables. Esta ponderación, nuevamente, ha de tenerse en cuenta no sólo en relación del patrimonio del autor, sino también de la persona jurídica.

Otro aspecto a considerar en cuanto a la persona jurídica como tercero civilmente responsable, es la configuración de un Derecho Penal de personas jurídicas como una tercera vía, esta tercera vía consistiría en establecer unas "medidas penales contra personas jurídicas" como unas "formas distintas de actuación del derecho penal" ${ }^{32}$, y pasando primeramente por la posibilidad de exigir a la persona jurídica, la responsabilidad administrativa, luego la civil como tercero y por último la responsabilidad penal. Por cuanto, sería una posibilidad nueva para considerar la responsabilidad civil del tercero en un proceso penal.

\section{LA PERSONA JURÍDICA COMO TERCERO CIVILMENTE RESPONSABLE EN LOS PROCESOS PENALES CUBANOS}

\subsection{ANTECEDENTES}

Durante la colonia, en el país rigió mediante el Real Decreto de 23 de mayo de 1879, el Código Penal español de 1870, donde se regulaba la determinación de la responsabilidad civil dentro del proceso penal, como una forma directa para satisfacer en el proceso el interés material de la víctima del delito, además de extrapolar las costumbres europeas a la Isla.

Este antecedente, en principio, sentó las bases para que cuando se promulgara el Código de Defensa Social en $1936^{33}$ y desde su entrada en

\footnotetext{
32 GRACIA MARTÍN, Luis. Crítica de las modernas construcciones de una mal llamada responsabilidad penal de la persona jurídica. Revista Electrónica de Ciencia Penal y Criminología (en línea). 2016, núm. 18-05, p. 1-95.

33 G.O.Extraordinaria. No.108 de fecha 11 de abril de 1936.
} 
vigor en 1938, se decidiera continuar ofreciendo el mismo tratamiento a la responsabilidad civil ${ }^{34}$, solo se estableció una nueva modalidad para hacer efectiva la referida institución, que fue la conocida Caja de Resarcimiento, la que estuvo regida por varias normativas ${ }^{35}$, no obstante, constituyó un órgano intermediario entre la víctima y su victimario.

Respecto a los terceros civilmente responsables, son igualmente reconocidos expresamente en el Código de Defensa Social, como una institución importante en cuanto al logro del interés del perjudicado por el delito, cuando no fuese el acusado responsable civil, igualmente se hace mención a la persona jurídica como tercero civilmente responsable, en casos de responsabilidad civil extracontractual directa. ${ }^{36}$

Con las modificaciones que tienen lugar en nuestro país después de 1959, se hace necesario atemperar la legislación vigente, en este sentido se realizan varias modificaciones al Código de Defensa Social, hasta que el 15 de febrero de 1979 comienza a regir la Ley $21^{37}$ que fue el nuevo Código Penal, el primero de la etapa revolucionaria, que siguió los mismos pasos de las dos normas anteriores, así en su Libro I, Título X, Capítulo I, II y III reguló lo referido a la responsabilidad civil proveniente del delito. Este código mantuvo en su artículo 70 que..."el responsable penalmente lo es también civilmente por los daños y perjuicios causados por el delito. El Tribunal que conoce del delito declara las responsabilidades civiles y su extensión..."38

${ }^{34}$ Este cuerpo legal estableció la responsabilidad civil derivada de delito, en el Libro I, Título VI, desde el Capítulo I hasta el V, estipulando en su artículo 110 que "todo hecho sancionable lleva consigo la responsabilidad civil".

35 Ver más acerca de la Caja de Resarcimiento en: MENDOZA PÉREZ, Juan Carlos; CASTILLO TORRES, Elayne y HECHAVARRÍA CASTILLO, Richard. La responsabilidad civil: la verdadera semántica de la Caja de Resarcimientos. Revista Anales de la Facultad de Ciencias Jurídicas y Sociales. UNLP. Año 13 / No $46-2016$.

36 Ver más en GOITE PIERRE, Mayda; MÉNDEZ LÓPEZ, Mirna. La responsabilidad civil derivada del delito en Cuba: una institución entre dos normas. En: AA.CC. Comentarios a Leyes penales cubanas. Editorial UNIJURIS. La Habana. 2014. p. 295-296.

37 Ley 21 de 1979, Código Penal. G.O. Ordinaria No.3 de fecha 1 de marzo de 1979.

38 AGUILERA DE LA PAZ, Enrique. Comentarios a la Ley de Enjuiciamiento Criminal. Editorial Reus (S.A). 1924. 
Dedica un capítulo a la responsabilidad civil de los terceros y otro a la ejecución de las obligaciones civiles provenientes del delito, donde mantiene a la persona jurídica como un tipo de tercero civilmente responsable en su artículo $71 .^{39}$

Por su parte, la legislación adjetiva, durante el dominio español, se vio descrita por una imposición a la Isla de todas las normas legales acerca del proceso penal, la cual encontró su primer fundamento del sistema mixto, en la Ley de Enjuiciamiento Criminal del 14 de septiembre del año $1882^{40}$, la que se hizo extensiva a Cuba, por Real Decreto de 19 de octubre de 1888 y comenzó a regir el 1ro de enero de 1889.

Esta ley, en materia de exigencia de responsabilidad civil en el proceso penal, en su Título IV De las personas a quienes corresponde el ejercicio de las acciones que nacen de los delitos y faltas, prescribió la posibilidad del ejercicio de la acción civil por daños y perjuicios, resultantes de la comisión del delito, además de identificar al sujeto responsable del ejercicio de dicha acción ${ }^{41}$.

39 CAPITULO II. DE LA RESPONSABILIDAD CIVIL DE LOS TERCEROS. ARTÍCULO 71.- 1. Son responsables civilmente: a) los órganos y organismos del Estado, las empresas, las cooperativas y cualquier otra entidad económica que disponga de patrimonio, por los delitos que cometan sus funcionarios, empleados o miembros, en el ejercicio legítimo de sus cargos y sean declarados, por ello, exentos de responsabilidad penal; 2. Son responsables cívicamente, en defecto de los que lo sean penalmente; a) los órganos y organismos del Estado, las empresas, las organizaciones económicas estatales, las cooperativas y cualquier otra entidad económica, en caso de delitos cometidos por los funcionarios públicos, sus empleados o dependientes, en el ejercicio de los actos propios de su cargo; b) las organizaciones económicas que operan hoteles, casa de huéspedes, albergues u otros establecimientos análogos, en relación con las sustracciones de bienes de que sean víctimas los huéspedes, y siempre que éstos hayan cumplido las disposiciones que regulan la custodia y vigilancia de dichos bienes; c) las organizaciones económicas que operan vehículos de cualquier clase destinados al transporte de personas y cosas, con motivo de los delitos cometidos por sus conductores en ocasión de la prestación de dicho servicio; ch) las entidades y personas privadas por los delitos cometidos por su empleador en el ejercicio de sus funciones.

40 Tomada de: <https://searchworks.stanford.edu/view/9948868>. Consultado el 22 de abril de 2017.

41 Artículo 100. De todo delito o falta nace acción penal para el castigo del culpable, y puede nacer también acción civil para la restitución de la cosa, la reparación del daño y la indemnización de perjuicios causados por el hecho 
Además, esta Ley de Enjuiciamiento Criminal, refirió en su Título X De la responsabilidad civil de terceras personas, todo el contenido de la obligación en el proceso penal del tercero civilmente responsable, afiliándose en este sentido a la posición numerus clausus del Código Penal, pues remite a este para la definición de tipos de terceros civilmente responsables en el proceso; no obstante fue poco profunda la técnica de reacción de texto legal respecto a estos últimos, porque en el caso de las personas jurídicas, se deben tener en cuenta otros factores como domicilio, objeto social, patrimonio, a diferencia de las personas naturales.

Otros derechos normados en esta legislación española aplicada en Cuba, fue la solicitud de retención de las piezas de convicción, cuando el dueño fuese conocido, hasta tanto se ejercitase la acción civil, la contestación en forma de escrito de defensa y proposición de pruebas, una vez requeridos por el Tribunal con la entrega del escrito de acusación, asistencia o no al acto de juicio oral y la interposición de recursos procesales.

En cuanto a la contextualización del ordenamiento jurídico al proceso revolucionario cubano, se promulgó la primera ley de procedimiento penal revolucionaria, la Ley 1251 de junio de $1973^{42}$, la cual establecía los principios procesales socialistas y fue resultado del trabajo de las Comisiones de Estudios Jurídicos, creadas en abril de $1968^{43}$; en esta la persona jurídica como tercero civilmente responsable fue regulada de manera similar a la Ley de Enjuiciamiento Criminal.

Con el proceso de institucionalización del país, en 1975, tiene lugar el Primer Congreso del Partido Comunista, que delimitó la plataforma política del Estado Socialista y se promulga la Constitución en 1976, donde se conforman normativamente los elementos del sistema político socialista cubano. ${ }^{44}$ La promulgación de la Constitución implicó que varias de las normas fueran derogadas, para ajustarlas a lo que se derivaba del texto constitucional, entre ellas la Ley de Procedimiento Penal, y se

punible. Artículo 112. Ejercitada sólo la acción penal, se entenderá utilizada también la civil, a no ser que el dañado o perjudicado la renunciase o la reservase expresamente para ejercitarla después de terminado el juicio criminal, si a ello hubiere lugar.

42 Ley 1251 de 1973, Ley de Procedimiento Penal. G.O. de fecha 25 de junio de 1973.

43 FERNÁNDEZ PEREIRA, Julio A. Ob. cit. p. 20.

44 MENDOZA DÍAS, Juan. Ob. cit. p. 44. 
promulgó, la actual Ley No. 5, del 13 de agosto de 1977, de Procedimiento Penal; en la que se mantiene el reconocimiento de la persona jurídica como tercero civilmente responsable, aún en la más reciente modificación realizada por el Decreto-Ley 310 de mayo de 2013, que entró en vigor en octubre del mismo año.

Siendo así, la entrada en vigor de la Ley 62 el 30 de abril de 1988, actual Código Penal cubano, dejó de consignar expresamente todo el contenido de la responsabilidad civil derivada del delito, y pasa a ser estipulada solamente en la legislación civil, realizando una extensión para su aplicación como normas supletorias, convirtiéndose igualmente en una norma de reenvío, el cuerpo legal civil para la Ley de Procedimiento Penal.

\subsection{Particularidades normativas de la persona JuRídica COMO tercero CIVILMENTE RESPONSABLE EN EL PROCESO PENAL CUBANO.}

\section{Constitución de la República}

Las pautas valorativas de cualquier análisis en este sentido, deben de partir del texto constitucional ${ }^{45}$, en el cual se estipula en el artículo 10 el principio de Legalidad, en el contexto de cumplir lo reglamentado para el proceso cuando existe el tercero civilmente responsable, y dentro de estos se ubicaría a la persona jurídica y algunas regulaciones del Debido Proceso desde el artículo 56 hasta el 60 de la Constitución de la República de Cuba. ${ }^{46}$

\section{Código CIVIL}

El Código Civil cubano, al referirse a los terceros civilmente responsables, no lo hace desde esa definición, sino acerca de la Responsabilidad

45 Constitución de la República de Cuba. G.O. Extraordinaria No. 3 de fecha 31 de enero de 2003, con las reformas aprobadas por la Asamblea Nacional del Poder Popular en el XI Periodo Ordinario de sesiones de la III Legislatura, 1992, 2005.

46 Véase artículos de la Constitución de la República de Cuba. 
de las personas naturales y Responsabilidad de las personas jurídicas, en la sección tercera y cuarta respectivamente del Capítulo IV Actos Ilícitos. ${ }^{47}$

Las personas jurídicas como terceros civilmente responsables también reciben un tratamiento en el mencionado código, estas son las que están obligadas a reparar los daños y perjuicios provocados a otros por actos ilícitos causados por sus dirigentes, funcionarios y demás trabajadores en el ejercicio de sus funciones, sin perjuicio del derecho de repetir contra el culpable, especificando que cuando el acto ilícito es constitutivo de delito responde subsidiariamente. ${ }^{48}$

En este caso la persona jurídica puede resultar responsable civilmente de un hecho propio del cual es incapaz de responder pues solo las personas naturales pueden hacerlo por lo que va a ser llamada al proceso penal para juzgar su responsabilidad civil extracontractual directa en el caso de que la conducta dañina constituya delito y así responder por sus agentes o dependientes siempre y cuando el hecho se cometa en desarrollo de su objeto social.

Igualmente, el resarcimiento de la responsabilidad civil por los actos ilícitos penales, comprende la restitución del bien, la reparación del daño material, la indemnización de los perjuicios y la reparación del daño moral.

\section{Código Penal}

Por su parte, la Ley 62, Código Penal cubano ${ }^{49}$, regula lo concerniente a la Declaración y Ejecución de las Obligaciones Civiles Provenientes del Delito, a partir del Título X, artículo 70.1, partiendo del principio que el responsable penalmente lo es también civilmente por los daños y perjuicios causados por el delito, decidiendo que el Tribunal que conoce del delito fija la responsabilidad civil y su extensión, constituyéndose, una problemática en el orden penal la aplicación de esta institución.

47 Ley No. 59, Código Civil. G.O. Extraordinaria No. 9 de fecha 15 de octubre de 1987.

48 Véase artículo 95 del Código Civil cubano.

49 Ley No. 62, Código Penal. G.O. Especial No. 3 de fecha 30 de diciembre de 1987. 
En este sentido, se concuerda con GOITE y MÉNDEZ ${ }^{50}$, cuando exponen las siguientes dificultades, referidas sobre todo a la participación de la persona jurídica como tercero civilmente responsable:

- La participación desde la responsabilidad penal, aparece regulada en el artículo 18 del Código Penal, donde se establece que será exigible a los autores y a los cómplices. El Código Civil al delimitar las reglas a tener en cuenta para determinar el daño material y la indemnización de los perjuicios, fija que en el supuesto de ser varios responsables se hace atendiendo al grado de participación en el acto ilícito.

- El Código Civil establece como exención de la responsabilidad civil, las causas de justificación, sin embargo surge una dificultad, la obediencia debida, en el Código Penal, regula la misma, como parte de la llamada eximente que denomina el cumplimiento de un deber o el ejercicio de derecho, profesión, cargo u oficio.

- Se establecen términos diferentes para la prescripción de las acciones, la legislación sustantiva penal, fija dichos términos sobre la base de la sanción establecida en el tipo penal.

\section{Ley de Procedimiento Penal}

En cumplimiento con lo regulado en la legislación sustantiva civil y penal, en cuanto a los terceros civilmente responsables, nuestra Ley de Procedimiento Penal ${ }^{51}$ ofrece sucintamente un tratamiento a estos como sujetos procesales; la primera aparición se resalta en el Título III De la Recusación y Excusa, artículo 22 al señalar entre los sujetos que pueden recusar al acusado y posteriormente al acusado como responsable civilmente ${ }^{52}$.

50 GOITE Y MÉNDEZ. Ob. cit. p. 308-310.

51 Ley No.5 de 1977, Ley de Procedimiento Penal. G.O. Ordinaria No.37 de fecha 26 de agosto de 1977.

52 ARTÍCULO 22.-Pueden recusar: 1. El Fiscal; 2. el acusador particular en los casos en que esta Ley permita su intervención; 3. el acusado; 4. el acusado como responsable civilmente. 
En el análisis exegético de este particular, se percibe que el legislador cubano no marcó una nítida frontera entre lo que considera él por acusado, y quién sería entonces el acusado civilmente responsable, porque teniendo en cuenta que como se resaltara en el Código Penal y la propia Ley de procedimiento, la acción civil y la penal se ejercen conjuntamente, entonces bastaría con señalar solamente al acusado, pero si lo que se quiere es denotar la responsabilidad civil cuando se exige a un sujeto distinto al acusado, entonces la denominación correcta sería la de tercero civilmente responsable (persona natural o jurídica) y no "acusado como responsable civilmente".

En este sentido, su correcta apreciación por parte del Tribunal, debe identificar a dos sujetos procesales, que independientemente de que ambos representen la cara visible del proceso penal, uno va a limitar su participación en el mismo con la responsabilidad civil, lo que no hace de su participación el centro del proceso, pero si resulta de vital importancia para la efectividad de la justicia penal.

Posteriormente en el Libro Tercero, Título II De la Responsabilidad Civil Derivada del Delito, artículo 275, se estipula que la acción para reclamar la responsabilidad civil que se derive del delito, se ejercita conjuntamente con la penal, excepto en el caso en que exista un lesionado respecto al cual la sanidad estuviere pendiente de atestarse.

Un aspecto relevante, es que en el artículo 277 comienza haciendo referencia al término tercero civilmente responsable, sin previamente haberse dado una conceptualización de quienes van a ser estos sujetos, y ni siquiera haberlos reconocido como sujeto procesal inicialmente, cuestión esta que dificulta la labor interpretativa del operador del Derecho, no obstante, se debe inferir que un embargo de bienes sobre un tercero civilmente responsable, ubicaría inmediatamente a este, como parte civil del proceso penal en cuestión, incluso a la persona jurídica, amén de las particularidades que se deben correr para presentarse como persona jurídica al proceso penal.

Respecto al escrito de calificación del Fiscal o el acusador particular, en el artículo 279, se prescribe que la acción civil, para ejercitarse conjuntamente con la penal, deben ser consignados en el mismo los siguientes particulares:

- La cosa que haya de ser sustituida

- El modo en que ha de procederse para la exigencia de la responsabilidad civil por daño moral o perjuicios 
- La persona o personas que estén obligadas (No se realiza distinción entre personas naturales y jurídicas, por lo que se infiere que pueden ser ambas).

Norma, que ambiguamente se muestra de acuerdo, con la participación de terceros como responsables civiles, pues en su tercer apartado, define la persona o personas obligadas, que al realizar una interpretación literal, la persona o personas obligadas pueden ser, el acusado del proceso o un tercero en su defecto.

También sucede con los artículos 281 y 282, donde se señalan que una vez formuladas las conclusiones por el Fiscal o el acusador particular, el tribunal de estimar completas las diligencias, abrirá la causa a juicio oral y dispondrá se requiera a los acusados y terceros civilmente responsables, a fin de que se designen abogados para su defensa. ${ }^{53}$

O sea, aquí incluso se resalta que el tercero civilmente responsable va a ostentar los mismos derechos que el acusado, en cuanto a la defensa técnica y material, aspecto este que resulta singular, pues se está dejando al tercero sin un estatus procesal claro, otorgando en este momento la posibilidad de postulación procesal, pero en un estado anterior del proceso, no fue considerado como parte civil del proceso penal, realizándose en la mayoría las diligencias de investigación, limitando igualmente la posibilidad recusación casi solamente a la fase del debate de juicio oral antes de su inicio, el citado día en la sala

53 Artículo 281.-(Modificado) Formuladas las conclusiones por el Fiscal o, en su caso, por el acusador particular, el Tribunal, de estimar completas las diligencias necesarias para proceder, abrirá la causa a juicio oral, teniendo por hecho la calificación y dispondrá se requiera a los acusados y terceros civilmente responsables, con entrega de las copias presentadas, a fin de que designen Abogados para su defensa, de no tenerlos ya designados, bajo el apercibimiento de que, de no hacerlo en el acto o, a más tardar, dentro de cinco días hábiles, se les nombrará Defensor de oficio. Este artículo fue modificado por el artículo 3 del Decreto-Ley No. 151, "Modificativo de la Ley de Procedimiento Penal", de 10 de junio de 1994 (G.O. Ext. No. 6 de 10 de junio de 1994, pág. 16). Artículo 282.-(Modificado) Transcurrido el plazo de cinco días hábiles a que se refiere el Artículo anterior sin que los acusa-dos o los terceros civilmente responsables hayan hecho las designaciones de los Abogados de su elección, o no personados los mismos, se les designará de oficio, y se pro-cederá con estos en la forma que se determina en el Artículo siguiente. 
del Tribunal, más aún si se tratase de la persona jurídica como tercer civilmente responsable. ${ }^{54}$

Referente, a la interposición de los artículos de previo y especial pronunciamiento, el artículo 291, hace alusión al Fiscal y las demás partes, siendo vaga la definición, pues la intervención en el proceso de la persona jurídica como tercero civilmente responsable, a partir del requerimiento del Tribunal, citado artículo 281, le da la condición de parte civil a este, siendo un derecho la posibilidad de pronunciamiento respecto a lo normado en el artículo $290 .{ }^{55}$

54 Articulo 284. Las partes pueden formular sobre cada uno de los puntos objeto de la calificación dos o más conclusiones alternativas. Artículo 285.-Se acompañarán copias del escrito de calificación y de la lista de testigos para su entrega a cada uno de los que sean parte en la causa. Artículo 286.-Las partes pueden pedir que se practiquen de inmediato aquellas diligencias de prueba que por cualquier causa sea de temer que no se puedan practicar en el juicio oral. Artículo 287.-Presentados los escritos de calificación, el Tribunal admitirá mediante auto las pruebas que considere pertinentes y rechazará las demás. Contra el auto que admita pruebas o mande a practicar las que se hallen en el caso a que se refiere el Artículo anterior, no se da recurso alguno. Contra el que las rechaza en todo o en parte, podrá interponerse, en su día, en recurso de casación, si se prepara oportunamente con la correspondiente protesta presentada a más tardar al día siguiente de la notificación. En el mismo auto el Tribunal señalará el día en que, dentro de los veinte siguientes, deban comenzar las sesiones del juicio oral, a menos que existan razones que obliguen a señalarlo para fecha posterior. Artículo 288.-Admitidas las pruebas el Tribunal adoptará las disposiciones adecua-das para que puedan practicarse en la oportunidad en que el juicio haya de tener lugar. A ese objeto librará cuantos despachos sean necesarios y designará, en su caso, los peritos, haciéndoles saber su designación a los efectos de los Artículos 207 y 208.

55 Artículo 290. Son objeto de artículos de previo y especial pronunciamiento las cuestiones siguientes: 1 . La declinatoria de jurisdicción; 2 . la de cosa juzgada; 3. la de prescripción de la acción penal; 4 . la de amnistía; 5. la de falta de autorización para proceder, en los casos en que sea necesaria; 6 . la falta de denuncia de la persona legitima-da para formularla, en los casos en que, de acuerdo con la Ley, constituya un requisito para proceder. Artículo 291. El Fiscal, en el trámite de calificación, y las demás partes dentro de los tres primeros días del término concedido para evacuar conclusiones, pueden proponer las cuestiones expresadas en el Artículo anterior. Artículo 298. En el día siguiente al de la vista, si la hay, el Tribunal dictará auto resolviendo las cuestiones propuestas. Si las partes no han solicitado la celebración de vista, una vez decursado el término de prueba, el Tribunal dictará de inmediato auto resolviendo las cuestiones propuestas. 
La Ley de Procedimiento Penal en su artículo 311, menciona el orden de práctica de medios de prueba en el acto de juicio oral, distinguiendo a los terceros civilmente responsables como un sujeto procesal en condición de parte, siendo el segundo en declarar, no obstante, el Tribunal puede alterar dicho orden, siendo positivo este aspecto en la norma, aunque si se tratase de una persona jurídica sería justo escuchar a los miembros de la dirección colegida y no solo al presidente, director o gerente.

Luego, a partir del artículo 312, se hace alusión a la declaración de los acusados y terceros civilmente responsables, resaltando en el artículo 313 y de hecho último artículo en el que se mencionan los terceros civilmente responsables, que, de atribuirse en la calificación, responsabilidad civil a persona distinta del acusado, le asiste a aquella el mismo derecho que a este para prestar declaración o no. ${ }^{56}$

Es obvio, que cuando se manifiesta "responsabilidad civil a persona distinta del acusado" se está refiriendo a los terceros civilmente responsables, cuestión esta que se debe inferir, pues de la forma en que viene redactada es inconcebible su comprensión. Lo que sí es relevante de este acápite, es que el testimonio del tercero no es una obligación, sino que se deja al margen de su valoración, lo que resulta positivo para sus intereses, pues de esta forma si considera que el mismo puede ser lesivo para sus beneficios, pues sencillamente no lo ofrece, asumiéndose una posición igualitaria y de equiparación respecto al acusado, a modo de ver de la investigación, justa con este sujeto procesal, que hasta esta última fase del proceso habían sido lacerados sus derechos, más si se trata de una persona jurídica.

Y por otra parte, no es obligatoria la comparecencia de la persona a quien solo se atribuye responsabilidad civil al acto de juicio oral, criterio normativo que deja una puerta abierta a la posterior contradicción con la sentencia respecto a los intereses civiles, pero que define la finalidad

56 Artículo 313. De atribuirse en la calificación responsabilidad civil a persona distinta del acusado, le asiste a aquélla el mismo derecho que a éste para prestar o no declaración, en los términos expresados en el Artículo anterior. No es obligatoria la comparecencia de la persona a quien sólo se atribuya responsabilidad civil, pero será siempre indispensable su citación para dar comienzo al juicio oral. Su falta injustificada de asistencia a una de las sesiones, dispensará de la necesidad de tal citación para las que sucesivamente hayan de tener lugar. 
del proceso en cuestión y su naturaleza, o sea, la determinación y comprobación de un hecho delictivo, la determinación de características y circunstancias de los participantes y la consecuente sanción penal.

Por tanto, se puede determinar que en nuestra Ley de Procedimiento Penal se ofrece un insuficiente tratamiento de la persona jurídica como tercero civilmente responsable, ya que este, independientemente de que se haga alusión vagamente en algunos artículos a los terceros civilmente responsables de forma general, como se analizó, se deja al margen de la valoración del operador del Derecho varios aspectos y actos procesales de éste, no se le brinda un tratamiento como sujeto procesal independiente, se utilizan indistintamente los términos de "tercero civilmente responsables" y "acusado civil responsable", además de que no se conceptualiza y mucho menos se dejan claros cuales derechos le competen, a pesar de que en los pocos artículos en que aparece hayan elementos positivos que si se tienen en cuenta pueden unidos a un buen tratamiento traer a colación una correcta utilización de la institución.

Igualmente, la remisión de la Ley de Procedimiento al Código Penal y de este al Código Civil, hace más difícil, la regulación y consecuente participación de este tercero civilmente responsable en un proceso penal.

\subsection{Propuestas para el perfeccionamiento}

La participación de la persona jurídica como tercero civilmente responsable en los procesos penales, hasta principios de los años 90, fue real y efectiva, pues los tribunales cubanos, tenían como referencia las legislaciones penales anteriores, que desarrollaban a grandes rasgos la forma de participación, el estatus procesal y el contenido de la responsabilidad que era exigible; pero esta práctica fue en decadencia, en principio por las propias limitantes normativas que han quedado plasmadas en la presente investigación, y por otra parte, por el criterio de algunas salas penales, respecto a la imposibilidad de participación de los terceros civilmente responsables en el proceso penal, debido a la no inclusión del contenido de la responsabilidad exigible en el Código Penal.

En una encuesta aplicada a 60 profesionales del Derecho que ejercen en esta sede, de los cuales $66,7 \%$ pertenecen a los tribunales 
cubanos, casi no hacen referencia a la persona jurídica como tercero civilmente responsable, siendo en este momento, uno de los factores que conllevan a los indubitables errores en la práctica judicial, y por ende a una insatisfacción material de los intereses de la víctima del delito, siendo en la mayoría de los casos, el propio Estado cubano.

No obstante, en los últimos años, con la actualización del modelo económico cubano, se han tramitado procesos penales con la intervención de personas jurídicas como terceros civilmente responsables, tal es una causa del 2014, seguida por la Sala Segunda de lo Penal del Tribunal Provincial Popular de La Habana, que al valorar el abundante material probatorio de carácter documental, testifical y pericial aportado por la Fiscalía y los defensores, dictó sentencia, sancionando a las empresas Tokmakjian Group Inc., Tokmakjian Limited, CYMC Corp., Tokmakjian International Inc., y Perry Intertrade Inc, como terceros civilmente responsables por el actuar delictivo de VAHE CY TOKMAKJIAN.

Sin embargo, la acometida acera del reconocimiento de la persona jurídica como tercero civilmente responsable en los procesos penales, debe ser en igual sentido, normativa, de ello se presentan las siguientes:

Propuestas para perfeccionar la real intervención de los terceros civilmente responsables en los procesos penales cubanos

Teniendo como precedente, las limitaciones para la participación real y efectiva de la persona jurídica como tercero civilmente responsable en el proceso penal cubano, se establecen las siguientes propuestas de perfeccionamiento:

\section{Respecto al Código Penal:}

- Definición de responsabilidad civil proveniente del delito para la persona jurídica.

- Definición de los terceros civilmente responsables y tipología.

- Remisión adecuada a la legislación civil, designando al Código Civil en materia de Responsabilidad civil por actos ilícitos, como cuerpo legal supletorio y en función de qué hace la remisión. 


\section{Respecto a la Ley de Procedimiento Penal:}

- Reconocimiento de los sujetos procesales, y en especial, del tercero civilmente responsable como sujeto distinto del acusado, y dentro de estos a la persona jurídica.

- Identificar la actuación del tercero civilmente responsable en la fase preparatoria, sobre todo la de la persona jurídica (reconocer su participación en algunas diligencias de investigación y la posibilidad de declarar o no como testigo).

- Normar el contenido y forma de la exigencia de la responsabilidad civil de la persona jurídica como tercero en el proceso penal.

- Identificar expresamente el derecho de impugnación de las resoluciones del proceso, en especial judiciales.

\section{Conclusiones}

A manera de conclusiones se expresa:

No existe igualdad de criterio en la doctrina respecto a la consideración de la persona jurídica- tercero civilmente responsable como sujeto procesal del proceso penal, lo que dificulta su definición y estatus procesal.

No existe una participación significativa de la persona jurídica como tercero civilmente responsable en los procesos penales cubanos, que coadyuven con la materialización de los intereses materiales de las víctimas, por lo que se evidencia la ineficacia del sistema procesal penal.

Existen limitaciones normativas en cuanto a la exigencia de responsabilidad civil a la persona jurídica como tercero en los procesos penales cubanos, que propician el no reconocimiento normativo de esta y por ende una indefinición de concepto, derechos, facultades y garantías, siendo necesarias propuestas de modificación que contribuyan al perfeccionamiento del sistema procesal penal, en este sentido formulan las siguientes propuestas:

CÓDIGO PENAL - TÍTULO X - LA RESPONSABILDAD CIVIL PROVENIENTE DEL DELITO - CAPÍTULO I - DEL CONTENIDO DE LA RESPONSABILIDAD CIVIL 
ARTÍCULO 70.- 1. El responsable penalmente lo es también civilmente por los daños y perjuicios causados por el delito. El Tribunal que conoce del delito declara las responsabilidades civiles y su extensión, aplicando de forma supletoria y cuando sea necesario, las normas correspondientes de la Ley 59/1987, Código Civil cubano.

2. La responsabilidad civil comprende: a) la restitución de la cosa; b) la reparación del daño material; c) la indemnización del perjuicio; ch) la reparación del daño moral.

\section{CAPÍTULO II - LOS TERCEROS CIVILMENTE RESPONSABLES} ARTÍCULO 71.-1. Los terceros civilmente responsables pueden ser personas naturales y personas jurídicas.

2. En caso de no existir responsabilidad penal, son responsables civilmente: a) La persona jurídica responde por los daños causados por sus dirigentes, funcionarios o demás trabajadores que hayan actuado dentro de sus atribuciones o por obediencia debida, y que por esa circunstancia hayan sido declarados exentos de responsabilidad penal.

3. Son responsables civilmente, en defecto de los que lo sean penalmente: a) Las personas jurídicas están obligadas a reparar los daños y perjuicios causados a otros por actos ilícitos penales cometidos por sus dirigentes, funcionarios y demás trabajadores en el ejercicio de sus funciones, sin perjuicio del derecho que les asiste de repetir contra el culpable. Si el delito es cometido por los dirigentes, funcionarios o demás trabajadores en el indebido ejercicio de sus funciones, la persona jurídica responde subsidiariamente; b) las organizaciones económicas que operan hoteles, casa de huéspedes, albergues u otros establecimientos análogos, en relación con las sustracciones de bienes de que sean víctimas los huéspedes, y siempre que éstos hayan cumplido las disposiciones que regulan la custodia y vigilancia de dichos bienes; c) las organizaciones económicas que operan vehículos de cualquier clase destinados al transporte de personas y cosas, con motivo de los delitos cometidos por sus conductores en ocasión de la prestación de dicho servicio; d) las entidades y personas privadas por los delitos cometidos por su empleador en el ejercicio de sus funciones. LEY DE PROCEDIMIENTO PENAL - TÍTULO III - DE LOS SUJETOS PROCESALES - CAPÍTULO I - LOS SUJETOS EN EL PROCESO PENAL ARTÍCULO 22.- Son sujetos del proceso penal: 1. El Tribunal; 2. El Fiscal; 3. El acusador particular en los casos en que esta Ley 
permita su intervención; 4. El acusado; 5. El representante legal del acusado; 6 . El tercero civilmente responsable; 7 . Los testigos; 8. Los peritos; 9. Los instructores penales; 10 . Y cualquier otro sujeto que intervenga en el contenido esencial del proceso.

CAPÍTULO VII - LOS TERCEROS CIVILMENTE RESPONSABLES ARTÍCULO 28.- El tercero civilmente responsable será la persona que de acuerdo al Código Penal debe responder por los daños y perjuicios causados por el hecho punible no cometido por este.

ARTÍCULO 29.- El tercero civilmente responsable será admitido como parte civil en el proceso penal, una vez que se instituya como parte, el responsable penalmente, y tendrá los mismos derechos y facultades de las que goza el imputado respecto de la defensa de sus intereses civiles. La intervención como tercero le exime de su deber de declarar sobre el hecho punible

TÍTULO IV - DE LA RECUSACIÓN Y EXCUSA

ARTÍCULO 22(actualmente).- Pueden recusar: 1. El Fiscal; 2.

$\mathrm{El}$ acusador particular en los casos en que esta Ley permita su intervención; 3. El acusado 4. El tercero civilmente responsable.

En cuanto a las diligencias de fase preparatoria:

ARTÍCULO 132(actualmente).- Cuando al practicarse las diligencias enumeradas en los Artículos anteriores, exista alguna persona respecto a la cual se haya adoptado alguna medida cautelar como presunto autor del hecho sancionable, se le instruirá de su derecho de asistir, igualmente se instruirá al tercero civilmente responsable si fuese el caso...

ARTÚCULO 134 (actualmente).- De considerarse necesario, pueden participar en la reconstrucción de los hechos el acusado, el tercero civilmente responsable...

CAPÍTULO V (actualmente) - DE LA DECLARACIÓN DEL ACUSADO Y LOS TERCEROS CIVILMENTE RESPONSABLES

Se incorporaría en este sentido la siguiente norma:

ARTÍCULO 167.- La toma de declaración del tercero civilmente responsable se haría siguiendo las reglas establecidas para la declaración del acusado.

Por otra parte, en cuanto al Dictamen Pericial, se dispondría:

ARTÍCULO 214.- Tratándose de diligencias que no admiten dilación o que por su índole no sea susceptible de ulterior reproducción, debe practicarse con la asistencia del Fiscal; y se 
hará saber, siendo posible, al acusado y tercero civilmente responsables, en caso de existir, para que puedan designar, si es de su interés un defenso

\section{Bibliografía}

AGUILERA DE LA PAZ, Enrique. Comentarios a la Ley de Enjuiciamiento Criminal. Editorial Reus (S.A). 1924.

ÁLVAREZ TORRES Y COLS, Osvaldo. Generalidades del Derecho Procesal. En: Compilación de Temas de Derecho Procesal para Estudiantes de Derecho. Editorial Universitaria. La Habana. Cuba. 2012.

BAUMANN, Jurgen. Derecho procesal penal. Conceptos fundamentales y principios procesales. Introducción sobre la base de casos. Editorial Depalma. Buenos Aires. Argentina. 1986.

BODES TORRES, Jorge Leslie. Reflexiones sobre las etapas procesales y los sujetos responsables. Sociedad Mexicana de Criminología. Capítulo Nuevo León, A.C. México. 2008.

CAPILLA RONCERO, Francisco. La persona jurídica: funciones y disfunciones. Editorial Tecnos. Madrid. España. 1993.

CARNELUTTI, Francesco. Cuestiones sobre el proceso penal. Traducción de Santiago SENTÍS MELENDO. Editorial Librería del Foro S. A. Buenos Aires. Argentina. 1994.

CASTÁN TOBEÑAS, Jose. Derecho civil común y foral. Editorial Reus. Madrid. España. 1943.

CASTRO MORALES, Yudy. Caja de Resarcimiento: aún quedan muchas cuentas pendientes. Periódico Granma. Edición Impresa. 27 de abril de 2016.

CLARÍA OLMEDO, Jorge A. Actualizado por Vázquez Rossi, Jorge E. Derecho procesal penal. Tomo I. Editores Rubinzal-Culzoni. Buenos Aires. Argentina. 1998.

CÓRDOVA ÁNGOLO, Miguel. Anotaciones sobre el tercero civilmente responsable en el procedimiento penal colombiano. Revista Derecho Penal y Criminología, vol. 34, no. 96, enero-junio 2013, Bogotá, Universidad Externado de Colombia, 2013.

FAIRÉN GUILLÉN, Víctor. Teoría General del Derecho Procesal. Instituto de Investigaciones Jurídicas. Serie G. Estudios Doctrinales. No. 133. Universidad Nacional Autónoma de México. México. 1992. 
FERNÁNDEZ PEREIRA, Julio A. El Derecho Procesal Penal. Concepto y naturaleza del proceso penal. Evolución histórica. Los sistemas de enjuiciar. En: AA.C.C. Temas para el estudio del Derecho Procesal Penal. Editorial Félix Varela. La Habana. 2002.

FERRARA, Francisco. Teoría de las personas jurídicas. Editorial Reus. Madrid. España. 1929.

GALVEZ PUEBLA, Inés. La ejecución de la responsabilidad civil derivada del delito en Cuba. Tesis doctoral. Universidad de La Habana. Cuba. 2009.

GARCÍA CAVERO, Percy. La responsabilidad penal del administrador de hecho de la empresa: Criterios de imputación. Barcelona, J.M. Bosch, 1999.

GIL GIL, Alicia. Bases para la persecución penal de crímenes internacionales en España. Editorial Comares. Granada. España. 2006.

GOITE PIERRE, Mayda; MÉNDEZ LÓPEZ, Mirna. La responsabilidad civil derivada del delito en Cuba: una institución entre dos normas. En: AA.CC. Comentarios a Leyes penales cubanas. Editorial UNIJURIS. La Habana. 2014.

GRACIA MARTÍN, Luis. Crítica de las modernas construcciones de una mal llamada responsabilidad penal de la persona jurídica. Revista Electrónica de Ciencia Penal y Criminología (en línea). 2016, núm. 18-05.

LEVENNE, Ricardo. Manual de Derecho Procesal Penal. 2da edición. Tomo I. Editorial Depalma. Buenos Aires. Argentina. 1993.

MARIN, J.C. La acción civil en el nuevo Código Procesal chileno: su tratamiento procesal. Revista de Estudios de Justicia. Chile. 2005.

MEINI, Iván. Responsabilidad penal del empresario por los delitos cometidos por sus subordinados. Valencia, Tirant lo Blanch, 2003.

MENDOZA DÍAZ, Juan. Derecho procesal. Parte general. Edición Electrónica. La Habana. Cuba. 2014.

MENDOZA PÉREZ, Juan Carlos; CASTILLO TORRES, Elayne y HECHAVARRÍA CASTILLO, Richard. La responsabilidad civil: la verdadera semántica de la Caja de Resarcimientos. Revista Anales de la Facultad de Ciencias Jurídicas y Sociales. UNLP. Año 13 / Nº 46 - 2016.

MORAS MOM, Jorge R. Manual de Derecho Procesal Penal. Editorial LexisNexis Abeledo -Perrot. Buenos Aires. Argentina. 2004.

OLIVA SANTOS, Andrés. Los sujetos del proceso penal. En: Derecho Procesal Penal. Sexta Edición, Centro de Estudios Ramón Areces, Madrid, 2003. 
QUINTERO OLIVARES, Gonzalo: De la responsabilidad civil derivada de los delitos y faltas y de las costas procesales. En: QUINTERO OLIVARES (DIR.). Comentarios al nuevo código penal, Navarra, Aranzadi, 1999.

ROXIN, Claus. Derecho procesal penal. Editorial Editores del Puerto s.r.l. Buenos Aires. Argentina. 2000.

VÁZQUEZ ROSSI, Jorge E. Derecho Procesal Penal. Tomo II. El Proceso Penal. Editorial Rubinzal-Culzoni. Buenos Aires. Argentina. 1997.

ZUÑIGA RODRÍGUEZ, Laura. A propósito de la responsabilidad civil de la persona jurídica por delito. Tomado de: <http://www.perso.unifr.ch/derechopenal/assets/ files/articulos/a_20080527_54.pdf $>$.

\section{Informações adicionais e declarações dos autores (integridade científica)}

Agradecimentos (acknowledgement): MSc. Alcides Antúnez Sánchez, Profesor Auxiliar, por revisión final del contenido del manuscrito.

Declaração de conflito de interesses (conflict of interest declaration): a autora confirma que não há conflitos de interesse na realização das pesquisas expostas e na redação deste artigo.

Declaração de autoria e especificação das contribuições (declaration of authorship): todas e somente as pessoas que atendem os requisitos de autoria deste artigo estão listadas como autores; todos os coautores se responsabilizam integralmente por este trabalho em sua totalidade.

Declaração de ineditismo e originalidade (declaration of originality): A autora assegura que o texto integral aqui publicado não foi divulgado anteriormente em outro meio e que futura republicação somente se realizará com a indicação expressa da referência desta publicação original; também atesta que não há plágio de terceiros ou autoplágio. Os itens 1.1 e 1.2 são versões revisadas e atualizadas de trechos publicados anteriormente em: HIDALGO, Leaned Matos; SÁNCHEZ, Alcides Antúnez. Referencias en torno a la intervención de los terceros civilmente responsables en los procesos penales en Cuba. Ratio Juris, vol. 11, n. 23, 2016. 
Dados do processo editorial

(http://www.ibraspp.com.br/revista/index.php/RBDPP/about/editorialPolicies)

- Recebido em: 01/04/2018

- Controle preliminar e verificação de plágio: 01/04/2018

- Avaliação 1: 16/04/2018

- Avaliação 2: 19/04/2018

- Avaliação 3: 21/04/2018

- Deslocamento ao V4N3: 30/05/2018

- Decisão editorial preliminar: 18/06/2018

- Retorno rodada de correções: 06/07/2018

- Decisão editorial final: 14/07/2018
Equipe editorial envolvida

- Editor-chefe: 1 (VGV)

- Editor-associado: 1 (CRG)

- Revisores: 3

\section{COMO CITAR ESTE ARTIGO:}

MATOS HIDALGO, Leaned. Realidades normativas de la persona jurídica como tercero civilmente responsable en los procesos penales cubanos. Revista Brasileira de Direito Processual Penal, Porto Alegre, vol. 4, n. 3, p. 1177-1215, set./dez. 2018. https://doi.org/10.22197/rbdpp.v4i3.157

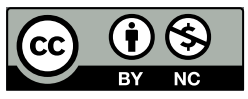

Esta obra está licenciada com uma Licença Creative Commons Atribuição-NãoComercial 4.0 Internacional. 